\title{
Discussions de la 2ème partie
}

\section{(2) OpenEdition}

1 Journals

Édition électronique

URL : https://journals.openedition.org/tc/618

DOI : $10.4000 /$ tc. 618

ISSN : 1952-420X

Éditeur

Éditions de l'EHESS

Édition imprimée

Date de publication : 1 septembre 1994

ISSN : 0248-6016

Référence électronique

"Discussions de la 2ème partie », Techniques \& Culture [En ligne], 21 | 1994, mis en ligne le 30

décembre 2005, consulté le 29 septembre 2022. URL : http://journals.openedition.org/tc/618 ; DOI :

https://doi.org/10.4000/tc.618

Ce document a été généré automatiquement le 29 septembre 2022.

Tous droits réservés 


\section{Discussions de la 2ème partie}

